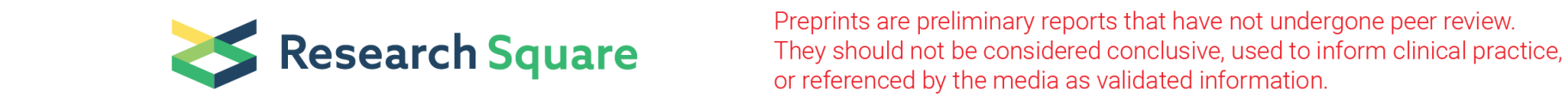

\title{
Earthquake hazard potential along the Panjal Thrust and the Zanskar Thrust, NW Himalaya
}

\author{
Bikram Singh Bali \\ University of Kashmir \\ Ahsan Afzal Wani ( $\square$ ahsanawani@gmail.com ) \\ University of Kashmir https://orcid.org/0000-0002-9906-499X
}

\begin{abstract}
Research Letter
Keywords: Northwest Himalaya, Pir Panjal range, Great Himalayan range, Kashmir Valley, Panjal Thrust (PT), Zanskar shear zone (ZT), Index of Relative Tectonic activity (IRTA)

Posted Date: September 9th, 2020

DOI: https://doi.org/10.21203/rs.3.rs-62862/v1

License: @ (i) This work is licensed under a Creative Commons Attribution 4.0 International License. Read Full License
\end{abstract}




\section{Abstract}

Kashmir basin is considered to be tectonically active where damaging earthquakes (historical and instrumental) and landslides have occurred. These geologic catastrophes make Kashmir valley prone to hazards. The fault bound Kashmir basin is marked by two mountain fronts: MF1 associated with the Panjal Thrust (PT) and Balapor Fault (BF) and MF2 associated with the Zanskar Thrust. These two structural units make Kashmir valley very susceptible to earthquakes. With this in view the whole basin was divided into 22 sub-basins. However only nine extreme north and south sub basins (five extreme southern and four northern extreme north) were studied to carry out relative tectonic activity of these two tectonic units. With the help of K-mean clustering of eight basin-related geomorphic indices (Hypsometric integral $(\mathrm{H} I)$, Asymmetry factor $(\mathrm{A} f)$, Mountain front sinuosity $\left(\mathrm{S}_{m f}\right)$, Basin shape (Circularity ratio $\left(\mathrm{K}_{A}\right)$ and Elongation ratio $\left.\left(E_{b}\right)\right)$, Form factor $(F f)$, Bifurcation ratio $\left(R_{b}\right)$ and Sinuosity index $(S i)$ were calculated. The results of the geomorphic indices were correlated with the structural and seismic data after that they were grouped into low three (Class 1 ), moderate (class2) and high (class3) relative tectonic activity zones based on the quantified geomorphic indices, earthquake data, structural data and field observations. The overall results infer the tectonic activity dies out towards the north of the Kashmir Valley. It was observed that the highest tectonic activity mostly corresponds to the sub basins in vicinity of the PT and BF stretching $100 \mathrm{Km}$ from Shopian to Baramulla. The least tectonic activity was found to be associated with the ZT lying to the north and northeast part of the Kashmir Valley. The seismic frequency and the overall data analysis infer that the south and Southwestern side of the Kashmir has potential of moderate earthquake in future.

\section{Introduction}

Tectonic geomorphology deals with the relation between tectonics and geomorphic processes shaping areas of active deformations (Burbank and Anderson, 2012; Decaillau et al.,1998; Molin et al.,1998).As the landscape contains an important evidence of the rate and spatial distribution of deformation. Therefore, geomorphic investigation in regions of tectonic deformation is a powerful tool for studies of tectonic geomorphology (Kirbby and Whipple, 2001). In order to measure and quantify the landscape change, evolution of geological structures, Seismic hazard assessment and study of landscape evolution, the calculation of geomorphic indices serves as a basic tool (Keller, 1986; Keller and Pinter, 2002).

Several authors have proposed different tectonic activity classes based on individual geomorphic indices (e.g., Taloor et al., 2017; Dey et al., 2016; Faghih et al., 2015; Khabazi et al., 2012; Dehbozorgi et al., 2010; El-Hamdouni et al., 2008; Silva et al., 2003; Raj et al.,1999, 2003; Chamyal et al., 2002; Rockwell et al., 1985; Bull and McFadden, 1977). Some of these classifications have concentrated on specific indices at specific site e.g., Kusky et al., 2010, 2016; Silva et al., 2003; Rockwell et al., 1985; Bull and McFadden, 1977. Moreover, El-Hamdouni et al. (2008) introduced a relative tectonic activity index (IAT) which is an arbitrary division of geomorphic indices into four different classes based on the summation and average of index values. The aim of this paper is to test a data mining technique of geomorphic indices to produce a single index that can be used to characterize relative active tectonics. For this purpose, one of the data mining methods known as "K means clustering" has been used for dividing geomorphic index values into homogeneous clusters followed by a discussion of the active tectonics based upon field-based structural evidences, earthquake frequency data and geomorphic observation.

The present study area is characterized by NW-SE trending faults, part of the MCT systems I,e Panjal Thrust and Zanskar Thrust (Fig. 1a \&1b) (Calkins et al., 1975; Bossart et al., 1988; Searle and Rex, 1989; Stephenson, et al.,1997; Bhat,1982). In the Southwestern part, subsidiary thrusts of the MCT system, namely the Panjal Thrust and out of sequence Balapora Fault cut through the Quarternary succession (Ahmed et al., 2013). As the result of the thrust motion and subsequent erosion, significant deformation in the form of beheaded streams, upliftment of terraces (Veshav, Sasara, Romushi and Rambiara), triangular facets, fault scarps have been preserved in response to the Panjal thrust and Balapora fault movement.

In the present study the tectonic geomorphology of the nine sub basins five from the Pir Panjal Range (PPR) and four from the Great Himalayan Range (GHR) have been studied. The tectonic geomorphology have been studied to characterize the relative tectonic activity of Pir Panjal sub-basins and the Great Himalayan sub-basins which have been effected by the Panjal Thrust (PT) and Zanskar Thrust (ZT) respectively.

\section{Geological And Tectonic Setting}


The tectonically active Himalayan fold thrust belt stretching east to west over a length of $2500 \mathrm{~km}$, formed as a result of the oblique convergence and ongoing collision of the Indian and the Eurasian plate $5 \mathrm{~cm} / \mathrm{Yr}$ (Gansser,1964; Lyon-Caen and Molnar, 1985; Avouac and Tapponnier, 1993; Schiffman et al.,2013; Kundu et al.,2014). The vertical and lateral growth of the Himalaya has been accommodated by several major south verging thrust systems. From north to south, these include the Zanskar thrust (ZT), Main Central Thrust (MCT/ PT), Balapora fault (BF), the Main Boundary Thrust (MBT), the Madlicottt Wadia Thrust (MWT) and the Main Frontal Thrust (MFT) (Figure. 1b) [Gansser, 1964; DeCelles et al., 2001; Schiffman et al., 2013; Wani and Bali, 2017]. All of these north dipping structures are rooted in the basal décollement, the Main Himalayan Thrust (MHT) (Ni and Barazangi, 1984; Nábělek et al., 2009; Dey et al., 2016). Although these thrust systems have propagated southward in an overall in-sequence pattern, however some out-of-sequence deformation has been reported. Wobus et al. (2005) proposed active out-of-sequence thrusting along the region known as the physiographic transition, south of the MCT in central Nepal. Out-of-sequence faults have also been reported by Ahmed and Bhat (2012) in Quarternary deposits Karewas of Kashmir, Mukul et al. (2007) in the Darjeeling Sub-Himalaya, by Thakur et al. (2007) between the MBT and the MFT near Dehradun, and by Powers et al. (1998) in the Kangra reentrant and the Jwalamukhi thrust in Shiwaliks of Himachal pradesh by Dey et al., (2016) of the NW Himalaya.

Kashmir valley is bounded by two major thrusts namely Main Central Thrust (MCT/PT) in the south and Zanskar Thrust (ZT) in the north (Bhat, 1982; Jaiswal et al., 2009). The Main Central Thrust/Panjal Thrust is steeply northeast dipping crustal shear zone, which is formed as a result of southward emplacement of a part of deeply rooted crust over the less metamorphosed sedimentary units of the Lesser Himalaya (Valdiya, 1980; Bhattacharya and Weber, 2004) and separates lesser Himalaya (a thick sequence of highly folded upper Precambrian sedimentary units with few outcrops of crystalline rocks) from tertiary Siwalik group towards south (Nakata,1989; Goswami and Pant,2007).Gently southwest-dipping Zanskar Thrust demarcating the north most boundary of the study area separates Kashmir valley from the Ladakh valley, the shear zone separates late Precambrian-Early Cambrian sedimentary sequence (Phe Formation) from the underlying crystalline basement (Zanskar Crystalline unit) (Herren,1987). In between these two tectonic domains lies the valley of Kashmir with $1300 \mathrm{~m}$ thick pile of Plio-Pleistocene sediments generally called Karewas dipping almost $40^{\circ}$ degrees towards the Northeast direction (Wadia, 1975; Bhat,1982; Burbank and Johnson, 1982).

The present study encompasses three major geotectonic domains I,e Greater Himalayan Range, Pir Panjal Range and the Valley floor, encompassing distinct lithological composition and structural pattern. The Great Himalayan range consists of Phyllite, Schists, Limestones, Panjal Traps, Graintes (Qazinag, Hant, Kangan), Agglomeratic slates whereas the Pir Panjal range consists the rock formations Especially Panjal Traps, Agglomeratic slates, Syringithyris limestones, Muth Quartzites and the Valley floor is mainly covered by the Plio-Pleistocene deposits (Karewas) and recent alluvium with major faults like balapora fault and already identified small faults. (Middlemiss,1911; Gnasser,1964; Ganju and Khar,1984; Sharma,1997; Thakur and Rawat,2002; Ahmed et al.,2013,2014; Bali et al.,2016; Ahmad et al,2017).

\section{Materials And Methods}

Geomorphic responses to tectonic activity were studied by analyzing geomorphic indices in addition drainage density and drainage anomalies were studied. Fault, fold growth and consequential interactions with the geomorphology of the area were studied through field observations. In this study we combine ArcGIS 10.1 (ESRI), Global mapper (16.0) for morphometric computing and IBM SPSS (21) and statistics for clustering analysis of morphometric parameters. Six geomorphic indices have been commonly employed by various workers (Keller and Pinter, 2002) to describe the tectonic deformation of an area. These are mountain front sinuosity ratio (Smf) (Bull, 1977, 1978; Bull and McFadden,1977), asymmetry factor (Af) (Hare and Gardner, 1985; Cox, 1994), hypsometric integral (Hi) (Strahler, 1952), Transverse topography symmetry(T)(Cox,1994), Stream length gradient index (SI) (Hack,1973) and Valley floor width to height ratio (Vf) (Keller and Pinter,1996). In the present study, eight geomorphic indices for nine watersheds were employed to infer the tectonic behavior of thrusts in the Kashmir Valley.

In order to describe the relative tectonic activity, we evaluate a data mining technique known as K-means clustering to find homogeneous clusters based on selected characteristics of geomorphic indices, earthquake data and field observations (Clare and Cohen, 2001; Pirkle et al., 1984). On the basis of K-clustering grouping the basins having same values were grouped under similar classes of tectonic activity. In order to represent how the procedure of clustering is done here we present the input and output tables of IBM SPSS (V-21) software processing for one of the calculated indices (Table1). At the first step the algorithm randomly chooses initial cluster centers for the 3 classes. Then the algorithm iteratively runs to attain cluster centers with no or small changes in cluster centers and they have maximum Euclidian distances from each other. In the next step the software has 7 output tables for clustering of each index, including initial cluster centers, iteration history, cluster membership, final cluster centers, distances between final cluster centers, 
ANOVA (analysis of variance) and number of cases in each cluster (Table 2). Also the field evidences, earthquake data and structural data was related to different classes for further inferences.

\section{Results}

The purpose of the present research is to examine the relative tectonic activities of the Kashmir Valley/Jhelum drainage basin with quantitative approach. In this regard, by doing research and exploring related literature, we found out that most researchers have investigated such parameters as mountain front sinuosity (Smf), the proportion of valley foot (Vf) to its height, percentage of continuous mountain fronts (Eu) and drainage networks analysis indices such as stream length (SL) gradient, asymmetry factor (AF) of the basin, and topography $(T)$ asymmetry factor. Hence, the authors have attempted to use indices less used before. With respect to the credibility of geomorphic indices in geomorphologic studies, Mountain front sinuosity(Smf), Elongation ratio(Eb),Circularity ratio (Ka), Bifurcation ratio $(\mathrm{Rb})$, hypsometrical integral ( $\mathrm{Hi})$, Assymetry factor(Af), Form factor(Ff) and mountain front sinuosity (Smf) indices have been calculated to evaluate the relative tectonic activities of Kashmir basin.

\section{Basin Asymmetry Factor (Af)}

The basin asymmetry factor gives the tilting direction of the basin and is expressed as(Hare and Gardner,1985)

\section{$A f=100 * A r / A t$}

Where $\mathrm{Ar}$ is the area of the basin to the right side of the trunk stream and At is the total area of the basin. Low values of $\mathrm{Af}=50 \mathrm{generally}$ are associated with symmetric basins whereas asymmetric basins are characterized by high $\mathrm{Af}>50$ or $\mathrm{Af}<50$ values (Giaconia et al., 2012). The obtained Af values varies between $70 \%$ (for sub-basin Veshaw) and $21 \%$ (for sub-basin Veshaw) in the study area. According to the K- means clustering, calculated Af values were clustered into three classes of high (4 sub-basins), moderate (2 sub-basins) and low (3 sub-basins) relative tectonic activity (Table 1). The values of the Af shows the tilting direction of the basin the values $>50$ indicate the sub-basins have shifted up to the right side whereas the values $<50$ infer that the sub-basins have shifted up to the left side. The Af values in the study area shows majority of the sub-basins have been influenced by tectonic activity. As the basins have either shifted up to the right side or shifted up to left side. The tectonic activity has developed unpaired river terraces with the Af values either $>50$ or $<50$. These inferences are well supported by the field investigations: presence of long and large tributaries to the tilted up side, development of unpaired river terraces and shifting of the trunk streams towards tilted down side of the basin.

\section{Hypsometric Integral (Hi)}

This index is defined as the area below the hypsometric curve and it varies from 0 to 1 . The HI is expressed as:

\section{$\mathrm{H} / \mathrm{H}_{\text {Mean }}-\mathrm{H}_{\text {Min }} / \mathrm{H}_{M a x}-\mathrm{H}_{M i n}$}

$\mathrm{Hi}$ values close to 0 infer highly eroded basins and values close to unity indicate less erosion activity. The resulting values of Hi range from 0.23 (for sub-basins Doodhganga and Pohru) to 0.51 (for sub-basin Veshaw). The obtained values were clustered into three classes of high, moderate and low relative tectonic activity (Fig. 4). Four sub-basins falls under high risk and three sub basin comes under moderate and two sub basins were classifies into low classes with moderate and low risk in terms of erosion an tectonic activity. The calculated values for $\mathrm{Hi}$ index in the study area show that about $64.5 \%$ of the sub-basins are possibly related to highly active tectonics with high erosion risk.

\section{Mountain Front Sinuosity (Smf)}

Mountain front sinuosity ( $\mathrm{S} m f$ ) is an index which shows the balance and equilibrium between climatic conditions, erosive forces and tectonic forces which is the cause of straight mountain front which are correspondent with mutant mountains with active fault. Sinuosity of mountain front is defined as below;

\section{$\mathrm{S} m f=\mathrm{L} m f / \mathrm{L} s$}

Smf: sinuosity of mountain front Lmf: length of mountain front along piedmont LS: length of the straight-line tangential to mountain front. Sinuosity index captures the struggle between erosive forces that try to erode mountain front in sinuous form and the tectonic force which creates a straight fronts. If erosive forces overcome, Smf produces a high rate, whereas when 
tectonic forces are active, Smf gives a lower value. In quantitative terms, the Smf index is between 1 and 1.6 for tectonically very active regions and is between 3 and 1.8 for regions with average activity and between 3 and higher for inactive mountain front (Madadi et al., 1983; Keller and Pinter, 1986, 2002; Wani et al., 2020). After clustering of the Smf results it was found that five sub-basins belong to the class 3 of tectonic activity with low values of Smf and linear mountain fronts, two sub-basins belong to class 2 of relative tectonic activity and two sub-basins belong to the class 1 of tectonic activity with higher values of Smf and irregular mountain fronts.

\section{Elongation ratio $(\mathrm{Eb})$}

Elongation ratio $(\mathrm{Eb})$ is the ratio between the diameter $(\mathrm{Ab})$ of a circle of the same area as the drainage basin and basin length (Lb) (Schumm, 1956), and is calculated as:

\section{$E b=2 \sqrt{A b} / \pi / L b$}

Where $A b$ is the diameter of the circle having same area as that of the basin and $L b$ is the length of basin. The values of elongation ratio vary from zero (highly elongated shape) to one (circular shape). Values close to 1.0 are typical of regions of very low relief whereas that of high values are associated with circular basins (Strahler, 1964). The EB of the sub-basins ranges from is 0.09 (Sindh sub-basin) to 0.17 (Erin and Pohru). The lower values of Eb indicates the elongated character of the sub-basins with high relief and steep slopes. The value of Eb for the sub-basins is shown in Table 1. The K-mean clustering of the sub-basins shows two sub-basins belong to the class 1 of tectonic activity with circular shape and five basins belong to the class 3 with more elongate shape and only 2 sub-basins belong to the class 2 of relative tectonic activity.

\section{Circularity ratio $(\mathrm{Ka})$}

The circulatory ratio $(\mathrm{Ka})$ has been used as a quantitative measure and is expressed as the ratio of the basin area $(\mathrm{A})$ to the area of a circle having the same perimeter as the basin (Miller, 1953;

Strahler, 1964) and is expressed as:

\section{$\mathrm{Ka}=4 \pi \mathrm{A} / \mathrm{P2}$}

Where $\mathrm{A}=$ area of the basin and $\mathrm{P}=$ perimeter of the basin. The values of circularity index varies from zero (for a line) to unity i.e. one (for a circle). The higher is the value of Ka, the more circular is the shape of the basin. The circulatory ratio is influenced by length, frequency of streams (Fs), geological structures, landcover, climate, relief and slope of the basin. It is significant ratio, which indicates the stage of the basin. Its low, medium and high values are indicative of the youth, mature and old stages of the lifecycles of the basins (Sreedevi et al., 2005, 2009). The Ka of the sub-basins ranges between 0.24 (Romushi sub-basin) and 0.57 (Pohru sub-basin) (Table 1).From the clustering of the Ka, it was found out of nine sub-basins five belong to class 3 , two belong to the class 2 and two sub-basins belong to class 1 of relative tectonic activity. The lower values correspond to the elongate and youthful basins and higher values correspond to the circular basins which are in old stage of development.

\section{Bifurcation ratio}

Bifurcation is referred to the ratio of the number of streams of given order to the number of streams of the higher degree The higher the bifurcation ratio value, the more tectonically active and the younger is the basin. These conditions result in multiplication of lower degree drainages. Lower bifurcation ratio is characteristic of basins with less structural agitation and whose drainage pattern is not unnatural. This index is obtained from relation

\section{$\mathrm{Rb}=\mathrm{Nu} / \mathrm{Nu}+1$}

Where $\mathrm{Nu}$ is the number of streams of given order and $\mathrm{Nu}+1$ is the number of streams of next higher order. According to the calculations, the sub-basin of Kashmir basin with the highest bifurcation ratio of 5.10 (Romushi) is the most active sub-basin and the Kashmir basin with lowest bifurcation ratio of 3.08(Erin) is considered the least tectonically active sub-basin. A perusal of structural map ascertains the above points because the southern sub basins are recognized as the most active sub basin as an important faults (Balapora fault) passes through them. As a playa, the sub-basins of Jhelum river towards north which contains no important structures are relatively less active than southern sub basins. 


\section{Form factor (Ff)}

The $\mathrm{Ff}$ of a drainage basin is expressed as a ratio between the area of the basin (A) and the square of the basin length (L2) (Horton, 1945), and is expressed as:

\section{$F f=A / L^{2}$}

The value of form factor is always towards higher side (for a perfectly circular basin). Smaller the value of form factor, more elongated is the basin. The $\mathrm{Ff}$ of the sub-basins ranges from 0.20 to 0.70 (Table 1).The pohru and Erin sub-basin with high Ff indicating circular shape comes under class 1 of lat have lowest tectonic activity, whereas elongated sub-basins with low form factor have highest tectonic activity of class2 and 3 (Chopra et al., 2005; Bali et al.,2012;Bali et al.,2016).

The lowest values of the form factor of the sub-basins from the Pir Panjal side indicate that the basins are highly elongate and tectonically more active than the sub-basins from the great Himalayan side. The highest value of $\mathrm{Ff}(0.70)$ was found in the Pohru subbasin and the lowest value of $\mathrm{Ff}(0.19)$ was found in the Rambaria sub-basin. From the $\mathrm{K}$-mean clustering it was found that 3 sub basins belong to the class 1 , three sub-basins belong to class 3 and only one sub basin comes under class 2 of relative tectonic active class.

\section{Sinuosity index (Si)}

The river sinuosity is defined as a ratio of the actual length of the channel to the length of a straight line measured from source to the mouth of a river. The river sinuosity can be considered to efficiently reflect the local bending degree (Bai \& Yang, 2011). It is expressed as:

\section{$\mathrm{SI}=\mathrm{CL} / \mathrm{VL}$}

Where $\mathrm{CL}$ is the channel length and VL is the valley length. The values of SI less than 1.5 indicates straight rivers, 1.5 represents braided pattern and $>1.5$ shows meandering pattern (Keller and Pinter, 1986). The higher values of river sinuosity are found from the southern side (Pir Panjal Range) showing highest bending degree or meandering pattern. However the low values of river sinuosity is found towards the northern side of the Kashmir valley (Great Himalayan Range). The higher values towards the southern side may possibly be because of the Balapora fault which crosses the Rambaria, Veshaw, Romushi and Doodhganga (Ahmed et al.,2013, 2014). The fault has offset the rivers at many places which change the course of rivers from straight to meandering type, the rivers have also preserved the braided bars below the fault intersection with the rivers. However the presence of hard rock and the high gradient of the rivers towards the northern side of the Kashmir valley have conserved the straight course of these rivers (Raza et al., 1978; Bali et al., 2016; Wani et al.,2019).

\section{Seismicity}

The study area comes under the Zone V in the Seismic Zonation map of India (1996). As the area is bound by two well-known fault systems, i.e. by Panjal thrust on the southern side and Zanskar Thrust on the northern side (Bhat, 1982; Walker et al., 2001). Moreover, the area is dissected by a number of smaller faults and thrusts, Balapora fault and other faults identified by Middlemiss making the area prone to earthquakes, as the Balapora fault has not shown any activity in the past therefore the area is under high seismic risk (Middlemiss,1910, 1911; Hough et al., 2009; Madden et al., 2011;Ahmed et al.,2014). The neotectonic activity in the area is well documented by the occurrence of a number of seismic events in the form of earthquakes and neotectonic features (Faults) and liquefaction features present in the Karewa deposits of Plio-Pleistocene age. Historic and recorded (1972-2016 from NEIC catalogue) seismic activity of the region in and around the study area, reveals that the region has experienced a number of low magnitude ( $<5 \mathrm{mb})$ high frequency seismic events and historical earthquakes which have destructed the Kashmir valley time to time e.g. Baramulla earthquake of 1885, Nilnag Budgam 1885, Kondabal earthquake of 1887 and the Wular/Sandimatnagar earthquake of $2082-2041$ BC (Fig.2) (Ahmad et al., 2009,2014, 2015; Bilham,et al.,2010; Bilham and Bali, 2013). The seismic pattern in the southern part of the Kashmir valley makes it more vulnerable to earthquakes and seismically at high risk with potential for moderate earthquake in future. These $1500 \mathrm{~m}$ disposed Karewa deposits above the valley floor shows tilting $40^{\circ}$ due northeast (Fig.5A\&B). Such a disruption of the 
bedding is being attributed to neotectonic activity due to Panjal thrust in the area. At Balapora village, the Rambaria River shows braiding and beheaded pattern with the development of unpaired river terraces (Ahmed et al, 2013). Also the fault has been identified near the Raithan area of Budgam which has preserved number of geomorphic features like Opposite dipping karewa beds, Braiding of river, Meander in this part of the river and unpaired river terraces (Fig. 7A, B, C \& D). Moreover, near Tangmarg village,

asymmetrica/unpaired river terraces are present on the sides of the Veshaw river (Fig. 5C \&D). In the Southwestern part of the study area many small faults have also been observed in the Pleistocene Karewa deposits indicating the neotectonic activity in the area

(Fig.6a,b,c,d). These neotectonic features and the Balapora fault makes the southern and southwestern part of the Kashmir Valley more susceptible to seismic hazards.

\section{Discussion}

The statistical summary of obtained values for each of the indices is presented in Table 1\&2. The average of the eight measured geomorphic indices ( $\mathrm{Smf}, \mathrm{Sl}, \mathrm{Af}, \mathrm{Hi}, \mathrm{Rb}, \mathrm{Ka}, \mathrm{Ff}$ and $\mathrm{Eb}$ ) was used to evaluate the distribution of relative tectonic and hazard activity. The values of the index were divided into three classes to define the degree of tectonic activity: 1-low, 2-Moderate and 3-high by averaging the eight geomorphic indices (El Hamdouni et al., 2008; Wani and Bali, 2017). The distribution of these three classes is shown in (Fig. 4). In high relative tectonic and hazard class following seismicity parameters and tectonogeomorphic features were observed: high frequency small magnitude earthquakes, presence of large magnitude historical earthquakes (Fig. 3), class 3 of lat, presence of high angle thrust fault (Balapora fault) which is almost silent in historical records, unpaired river terraces in the Veshaw (Fig. 5C\&D), Rambaria and Sasara river basins. In addition to the unpaired river terraces the presence of the highly elongated river basins, with convex up longitudinal profiles, parallel drainage pattern with offset streams near Balapora, Tangmarg and Raithan are the factors responsible for the high tectonic activity in this part of the Kashmir valley. In addition to the above tectonogeomorphic features the braided streams, incised valleys, linear mountain fronts, elongate basins, low bifurcation and elongation ratio in the southern part of the area and presence of faults (Panjal thrust, Balapora fault and other small faults) which have formed important anticlines and fault scarp near Shopian, beheaded and offset streams above Shopian town (Ahmed et al.,2012, 2013). Also the Balapora fault has thrusted $9 \mathrm{~m}$ Pampur member over the Shopian member which is clearly visible near Balapora village (Ahmed et al., 2013). The uplift along the Panjal thrust has deformed the Karewa beds towards northeast at an angle of $40^{\circ}$ (Fig. 5A\&B). Balapora fault and other small faults in the Karewas with the development of tectonogeomorphic features can be a reason for the increase in relative tectonic activity towards the southern fringe of the study area. High tectonic activity based on lat, already published literature and field observations suggest high tectonic activity widespread towards the southern ans southwestern part of the area. Based on Arian and Hashemi (2008), this area is under high seismic risk, with the chance of moderate earthquake in future. Because the area contains some smaller faults like tangmarg and Raithan faults which were identified in the field by preserving some geomorphic features like meandering, braiding and offset stream near tangmarg and opposite dipping karewa beds near Raithan. The beds dip towards the SW and NE on the right and left side of the fault plane facing South.

However in the north part of the area, the less elongate basins with moderate smf values, low bifurcation ratio values, high form factor and least frequency earthquakes and lesser number structures in the form of faults, folds, incised valleys and straight river course led to decrease in the relative tectonic activity to moderate and low classes. The reason may be because of the presence of inactive/less active Zanskar Thrustin the vicinity of the great Himalayan basins.

\section{Conclusions}

After the calculation and classification of geomorphic indices on the basis of K-mean clustering. It seems that the calculated geomorphic indices are suitable for assessment of the tectonic activity of the study area. The geomorphic indices such as drainage basin asymmetry (Af), hypsometric integral (Hi), elongation and circulatory ratio, form factor, sinuosity index and mountain-front sinuosity (Smf) are calculated for nine sub basins of the Kashmir valley. The geomorphic analysis for nine basins: five from Pir Panjal Range and four from Great Himalayan Range was carried out, then all of the indices were divided into three classes: high, moderate, and low based on the quantification of geomorphic indices (K-mean clustering), seismic activity and field evidences. Afterwards, eight measured indices for each sub-basin were compounded and a unit index was obtained as the relative tectonic activity (lat). The area and occupation percentage for each class of index were calculated. As can be seen in (Table 2E), most of the high percentages in the area are located in class 3, which shows high tectonic activity. The total area under class 3 (lat) covers an area of about $3394 \mathrm{~km}^{2}$ (47\%), class 2 (lat) with an area of about $2053 \mathrm{~km}^{2}(28 \%)$, class 1 (lat) with an area of about $2070 \mathrm{~km}^{2}(25 \%)$. It was observed that the Class 3 is located in vicinity of Panjal thrust, Balapora fault, identified faults near Raithan, and Tangmarg and some major anticlines, 
class 2 is Scattered to the north-eastern part of the Himalayan range, class 1 is confined to the northern border of the study area. Most of the areas with high tectonic activity values of lat are located in the vicinity of the Panjal thrust and Balapora fault has high seismic/earthquake frequency. Seismic pattern and occurrence of low magnitude high frequency earthquakes in the region implies the area has potential for moderate earthquake in future. Thus all the research concludes the area or the sub basins with class 3 of lat is under high seismic risk. The statistical results infer that the Eb and Ka has highest positive correlation followed by $\mathrm{Ff}$ and Ka and Eb and $\mathrm{Ff}$. The highest negative correlation was observed in $\mathrm{Ff}$ and $\mathrm{Hi}$ followed by $\mathrm{Si}$ and $\mathrm{Rb}$. From the ANOVA analysis highest significance level is found in Af and least significance level is observed in Si. Also the results of this paper confirm previous research in this region.

\section{Declarations}

\section{Availability of data and materials}

The authors confirm that the data supporting the findings of this study are available within the article and should be made available after corresponding author's approval.

\section{Competing Interest}

1) All authors have participated in (a) conception and design, or analysis and interpretation of the data; (b) drafting the article or revising it critically for important intellectual content; and (c) approval of the final version.

\section{Funding}

Not applicable

\section{Acknowledgements}

The Authors highly acknowledge the Department of Earth sciences, University of Kashmir for providing Lab. Facilities to carry out the work and providing software's for data preparation.

\section{References}

Ahmad, B., Bhat M.I., Bali B.S., 2009. Historical record of earthquakes in the Kashmir Valley. Himalayan Geology, 30(1), 75-84

Ahmad, B. Sana,H., Alam,A., 2013 Macroseismic intensity assessmentof 1855 earthquake of northwest Kashmir Himalaya, using environmental seismic intensity scale (ESI2007). Quarternary international, xxx(2013),1-6.

Ahmad, B. and Shafi, M., 2014. Some more earthquakes from medival Kashmir. Journal of Seismology,1383-4649.

Ahmad, B., Ahmed, S., Alam, A., Wang, S., Bhat, M. S., 2015. Looking for Missing Links in Kashmir: An Update on Nineteenth-Century Seismicity. Seismological Research Letters 86 (4),1-6.

Ahmed, S., Bhat, M. I., 2012. Tectonic geomorphology of Rambiara basin, SW Kashmir Valley reveals emergent out-of-sequence active fault system.Himalayan Geology, Vol. 33(2), 162-172.

Ahmed, S., Bhat M. I., Madden, C., 2013.Geomorphic analysis reveals active tectonic deformation on the eastern flank of the Pir Panjal Range, Kashmir Valley India. Arab J Geo sciences,6,1-11.

Ahmed, S., Bhat, M. I., Ahmad, B., Alam, A., 2014.Late Quaternary landforms generated by the Balapur fault and its kinematic analysis on the northeastern flank of the Pir Panjal Range, Kashmir Valley, India.International Geographical union(IGU). Conference paper,4th -5th june 2014.

Ahmed,S., Alam,A., Ahmad,B., Bhat,M.I., Bhat,M.S., 2015. Geomorphic evidences of unrecognized Balapur fault segment in the southwest Kashmir basin of Northwest Himalaya. Geomorphology, 159-172. 
Ahmed,S., Alam,A., Ahmad,B., Wani,A.A., Bhat,M.I., Bhat,M.S.,Farooq,H. 2018. Tectono-Geomorphic indices of Erin Basin, Northeast Kashmir valley,India. Asian Earth Sciences, 151,16-30.

Arian, M. and Hashemi, A. 2008. Seismotectonic Zoning in the Zagros. Journal of Sciences, 18, 63-76.

Avouac, J., Tapponnier, P., 1993. Kinematic model of active deformation in central Asia,Geophys. Res. Lett., 20, 895-898, doi:10.1029/ 93GL00128.

Bai, Y. C., Yang, Y. H., 2011. The dynamic stability of the flow in a meander channel. Science China Technological Sciences, 54, 931940.

Bali, R., Agarwal, K.K., Ali, S.N., 2012. Drainage morphometry of Himalayan Glacio-fluvial basin, India: hydrologic and neotectonic implication. Environ Earth Sci. 66(4):1163-1174.

Bali, B. S., Wani, A. A., Khan, R. A.. Ahmed, S., 2016. Morphotectonic analysis of the Madhumati watershed, Northeast Kashmir Valley. Arabian Journal of Geosciences, 9(5), 1-17.

Bhat, M. I., 1982.Thermal and Tectonic evolution of Kashmir basin, Vis-Vis petroleum prospects. Tectonophysics, 88(1-2), 117-132.

Bhat M. I, Malik M. A, Bali B. S., 2008. Tectonic geomorphology of the Pir Panjal Range. Workshop on October 8, 2005 Kashmir Earthquake and after. Jam Univ. pp. 39-42.

Bhattacharya, A. R.,Weber, K., 2004. Fabric development during shear deformation in the Main Central Thrust Zone, NW-Himalaya, India. Tectonophysics, 387(1), 23-46.

Bilham, R., Bali,B.S., Bhat,M. I., Hough, S., 2010. Historical earthquakes in Srinagar, Kashmir: clues from the Shiva temple at Pandrethan, GSA special paper 471 on ancient earthquakes, (edited by Manuel Sintubin, lain S. Stewart, TinaM. Niemi, and Erhan Altunel). ISBN 9780813724713

Bilham, R., Bali, B. S., 2013. A ninth century earthquake-induced landslide and flood in the Kashmir Valley, and earthquake damage to Kashmir's Medieval temples.Bulletin of Earthquake Engineering, DOI: 10.1007/s10518-013-9504-x.

Bossart, P., Dietrich,D.,Greco, A., Ottiger, R., Ramsay, J. G., 1988. The tectonic structure of the Hazara-Kashmir Syntaxis Southern Himalaya, Pakistan. Tectonics,7,273-297.

Bull W.B., 1977. Tectonic geomorphology of the Mojave Desert: Menlo Park, California, U.S.

Geological Survey Office of Earthquakes, Volcanoes, and Engineering Contract Report 14-08-001-G- $394,188$.

Bull W.B., McFadden L.D., 1977. Tectonic geomorphology north and south of the Garlock Fault, California, in arid regions: Proceedings Eighth Annual Geomorphic System, State University, New York, Binghamton: 115-138.

Burbank, D. W., \& Anderson, R. S., 2012. Tectonic geomorphology (2nd ed.). Chichester: Wiley-Blackwell.

Burbank D.W., Johnson, G.D., 1982.Intermontane-basin development in the past 4 Myr in the north-west Himalaya.Nature 298:432-436

Calkins, J.A., Oldfield, T.W., AMullah, S.K.M. \& Ali, S.T., 1975.Geology of the southern Himalayas in Hazara, Pakistan, and adjacent areas. U.S. 01. Surv. Prof. Paper 716-C, 29

Chamyal, L. S., Maurya D. M., Bhandari S., and Raj R., 2002 Late Quaternary geomorphic evolution of the lower Narmada valley, Western India: implications for neotectonic activity along the Narmada-Son Fault, Geomorphology, vol. 46, no. 3-4, pp. 177-202.

Chopra, R., Dhiman, R.D., Sharma, P.K., 2005. Morphometric analysis of sub-watersheds in Gurdaspur district, Punjab using remote sensing and GIS techniques.Journal of Indian Soc Rem Sens 33(4): 531-539

Clare, A. P., Cohen, D. R., 2001. A Comparison of Unsuper-vised Neural Networks and K-Means Clustering in the Analysis of Multi-Element Stream Sediment Data. Geochemistry: Exploration, Environment, Analysis, 1(2), 119-134.

Page 9/18 
Cox R.T., 1994. Analysis of drainage-basin symmetry as a rapid technique to identify areas of possible Quaternary tilt-block tectonics: an example from the Mississippi Embayment, Geological Society of America Bulletin, 106(5), 571-581.

Datta, N. K. 1983. Geology, Evolution and Hydrocarbon Prospects of Kashmir Valley. Jour. of Petroleum Asia, 177-178

DeCelles, P. G., Robinson, D. M., Quade, J. Ojha, T. P., Garzione, C. N., Copeland, P., Upreti, B. N., 2001. Stratigraphy, structure, and tectonic evolution of the Himalayan fold-thrust belt in western Nepal, Tectonics, 20, 487-509, doi:10.1029/2000TC001226.

Dehbozorgi, M., Pourkermani, M., Arian M., Matkan, A., Motamedi, H., Hosseiniasl, A. 2010. Quantitative analysis of relative tectonic activity in the Sarvestan area, central Zagros, Iran. Geomorphology, 121, 329-341.

Delcaillau, B., Amrhar, M., Namous, M., 2011. Trans- pressional Tectonics in the Marrakech High Atlas: Insight by the Geomorphic Evolution of Drainage Basins. Geomorphology, 134(3): 344-362

Delcaillau, B., Deffontaines, B., Floissac, L., Angelier, J., Deramond, J., Souquet, P., Chu, H.T., Lee, J., 1998. Morphotectonic evidence from lateral propagation of an active frontal fold; Pakuashan anticline, foothills of Taiwan. Geomorphology 24, 263-290.

Demoulin, A., 1998. Testing the tectonic significance of some parameters of longitudinal profiles: the case of the Ardenne (Belgium, NW Europe): Geomorphology, 24, 189-208.

Dey, S., Thiede, R. C., Schildgen, T. F., Wittmann, H., Bookhagen, B., Scherler, D., Strecker, M. R., 2016. Holocene internal shortening within the northwest Sub-Himalaya: Out-of-sequence faulting of the Jwalamukhi Thrust, India, Tectonics, 35.

El Hamdouni, R., Irigaray, C., Fernández, T., Chacón, J., Keller, E., 2008. Assessment of relative active tectonics, southwest border of the Sierra Nevada (southern Spain). Geomorphology 96, 150-173.

Faghih, A., Nourbakhsh, A., Kusky, T. M., 2015.GIS-Based Analysis of Relative Tectonic Activity along the Kazerun Fault Zone, Zagros Mountains, Iran: Insights from Data Mining of Geomorphic Data.Journal of Earth Science, 26(5), 712-723.

Gunj J. L and Khar B. M., 1984. Tectonics and Hydrocarbon Prospects of Kashmir Valley -Possible Exploratory Targets. Petroleum Asia Journal,1,207- 217.

Gansser, A., 1980. The significance of Himalayan Suture zone. Tectonophysics, 62, 37-52.

Giaconia, F., Booth-Rea, G., Martínez-Martínez, J.M., Azañón, J.M., Pérez-Peña, J.V., Pérez- Romero, J., Villegas, I., 2012. Geomorphic evidence of active tectonics in the Sierra Alhamilla (eastern Betics, SE Spain). Geomorphology 145-146, 90-106.

Gioia, D., Gallicchio, S., Moretti, M., Schiattarella, M., 2014. Landscape response to tectonic and climatic forcing in the foredeep of the southern Apennines, Italy: insights from Quaternary stratigraphy, quantitative geomorphic analysis, and denudation rate proxies. Earth Surface Processes and Landforms 39, 814-835.

Goswami, P. K., Pant, C ,C., 2007. Geomorphology and tectonics of Kota- Pawalgarh Duns, Central Kumaun Sub-Himalaya. Curr. Sci, 92(5), 685-690.

Hack, J.T., 1973. Stream-profile analysis and stream-gradient index. Journal of Research, U.S.

Geological Survey 1: 421-429.

Hare, P.W., Gardner T.W., 1985. Geomorphic indicators of vertical neotectonism along converging plate margins, Nicoya Peninsula, Costa Rica. In Morisawa M, Hack JT (eds) Pr Allen Unwin Boston Binghantom (15 th Annu Tec Geomorph Sym) Sept 1984.

Herren, E., 1987. Zanskar shear zone: Northeast-southwest extension within the Himalayas (Ladakh, India), Geology 15(5),409-413.

Hough,S.,Bilham,R.,Bhat,M.I.,2009. Kashmir Valley Megaearthquake, Estimates of the magnitudes of the past seismic events foretell a very shaky future for this pastoral valley.American Scientists,97,42-49.

Jaiswal, K. M., Bhat, M. I., Bali, B. S., Ahmed, A., Chen, Y. G., 2009. Luminescence characteristics of Quartz and Feldspar from tectonically uplifted terraces in Kashmir basin Jammu and Kashmir India. Radiation measurements.44, 523-528.

Page 10/18 
Keller, E. A., 1986. Investigation of active tectonics: use of surficial earth processes. In Panel on Active Tectonics, National Academy press: Washington DC, 138-147.

Keller, E.A., Pinter N.,1996. Active tectonics: Earthquakes, Uplift and Landscapes, Prentice Hall, New Jersey, 338.

Keller, E.A., Pinter N., 2002. Active tectonics: Earthquakes, uplift, and landscape (second edition): Englewood Cliffs, Prentice Hall, New Jersey,121-147.

Khabazi, H., Moayeri, M., Maryam, N., 2012.The Effect of Active Tectonics on Paleogeomophologic Transformations of Arid Zones (Case Study: Dagh-e- Sorkh Basin Playa in Iran Country).American Journal of Scientific Research, 63(2012),14-25. ISSN 2301-2005.

Kusky,T.M.,Polat,A.,Windely,B.F.,Burke,K.C.,Dewey,J.F.,Kidd,W.S.,Maruyama,S.,Wang,S.P.,Deng,H.,Wang,Z.S.,Wang,C.,Fu,D.Li,X.W.,Peng,H.T., 2016. Insights into the tectonic evolution of the north China Craton through the comparative tectonic analysis: A record of the outward growth of Precambrian continent. Earth Science Reviews,162,387-432.

Kundu, B., Yadav, R. K., Bali, B. S., Chowdhury, S., Gahalaut,V. K., 2014. Oblique convergence and slip partitioning in the NW Himalaya: Implications from GPS measurements, Tectonics, 33, doi:10.1002/2014TC003633.

Lyon-Caen, H., Molnar P., 1985. Gravity anomalies,flexure of Indian plate and the structure, support, and evolution of the Himalayan Ganga basin, Tectonics, 4, 513-538, doi:10.1029/TC004i006p00513.

Madadi, A., Rezaei, M.H., Rajai, A. M., 1983. Analyzing neotectonic activities using geomorphologic methods in northwestern foots of Talesh (Baghrodagh). Geographical Researches, pp.123-138.

Madden, C, Trench D, Meigs, A., Ahmad S, Bhat M.I., Yule, J.D., 2010. Late Quaternary Shortening and Earthquake Chronology of an Active Fault in the Kashmir Basin, Northwest Himalaya. Seismological Research Letters, 81 (2): 346.

Madden, C., Ahmad, S., Meigs, A., 2011. Geomorphic and paleoseismic evidence for late Quaternary deformation in the southwest Kashmir Valley, India: Out-of-sequence thrusting, or deformation above a structural ramp?," (Abstract-ID T54B-07) American Geophysical Union Fall Meeting.

Middlemiss, C. S., 1910.Revision of Silurian-Trias sequence of Kashmir; Rec. Geol. Survey of India 40 206-260.

Middlemiss, C. S., 1911. Sections in the Pir Panjal range and Sindh Valley, Kashmir; Rec. Geol. Survey of India (41),115-144.

Molin, P., Pazzaglia, F.J., Dramis, F., 2004. Geomorphic expression of active tectonics in a rapidly-deforming forearc, Sila Massif, Calabria, Southern Italy. American Journal of Science 304, 559-589.

Mukul, M., Jaiswal, M., Singhvi,A. K., 2007. Timing of recent out-of-sequence active deformation in the frontal Himalayan wedge: Insights from the Darjiling sub-Himalaya, India, Geology, 35(11), 999-1002, doi:10.1130/g23869a.1.

Nakata, T., 1989. Active faults of the Himalayas of India and Nepal. Spec Pap Geol Soc Am 232:243-264.

Nábělek, J., G. Hetényi, J., Vergne, S., Sapkota, B., Kafl e, M., Jiang, H., Su, J., Chen, B.S., Huang., 2009. Underplating in the HimalayaTibet Collision Zone Revealed by the Hi-CLIMB Experiment, Science, 325(5946), 1371-1374.

Ni, J., Barazangi, M., 1984. Seismotectonics of the Himalayan Collision Zone: Geometry of the underthrusting Indian Plate beneath the Himalaya, J. Geophys. Res., 89, 1147-1163, doi:10.1029/JB089iB02p01147.

Pike, R.J., Wilson S.E., 1971. Elevation relief ratio, hypsometric integral and geomorphic area-altitude analysis. Geol Soc Amer Bull 62, 1079-1084.

Pirkle, F. L., Howell, J. A., Wecksung, G. W., 1984. An Example of Cluster Analysis Applied to a Large Geologic Data Set: Aerial Radiometric Data from Copper Mountain, Wyoming. Journal of the International Association for Mathematical Geology, $16(5)$ : 479-498.

Powers, P. M., Lillie, R. J.,Yeats R. S., 1998. Structure and shortening of the Kangra and Dehra Dun reentrants, sub-Himalaya, India, Geol. Soc. Am. Bull., 110(8), 1010-1027, doi:10.1130/0016-7606. 
Raj,R.,Maurya,D.M.,Chamyal,L.S., 1999. Tectonic geomorphology of the Mahi River Basin,Western India. Journal of geological society of India, 54,387-398.

Raj,R.,Bhandari,S., Maurya,M., Chamyal,L.S.,2003. Geomorphic indicators of active tectonics in the Karjan river basin, Lower Narmada Valley, western India. Journal of geological society of India,62(6),739-752.

Raza, M., Ahmad, A., Mohammad, A., 1978. The Valley of Kashmir, A Geographical interpretation of the land, Vol.1, Vikas publishing house. pvt. Ltd, New Delhi.

Rockwell, T.K., Keller, E.A., Johnson, D.L., 1984. Tectonic geomorphology of alluvial fans and mountain fronts near Ventura, California. In: Morisawa, M., Hack, T.J. (Eds.), Tectonic Geomorphology. Publications in Geomorphology, State University of New York, Binghamton, pp. 183- 207.

Searle, M. P., and Rex, A. J., 1989. Thermal model for the Zanskar Himalaya. Journal of Metamorphic Geology,7, 127-134.

Schiffman, C., Bali B.S., Szeliga, W., Bilham R.,2013. Seismic slip deficit in the Kashmir Himalaya from GPS observations, Geophysical Research Letters, 40, 5642-5645

Schumm, S.A.,1956. Evolution of drainage systems and slope badlands at Perth Amboy,N. Geological society of America Bulletin,67,597-646.

Seeber L., Gomitz, V., (1983) River profiles along the Himalayan arc as indicators of active tectonics. Tectonophysics 92:335-367

Shah A. A., 2013. Earthquake geology of Kashmir Basin and its implications for future large earthquakes International Journal of Earth Sciences DOI 10.1007/s00531-013-0874-8.

Sharma,K.K.,1997. Granite Plutons in dominal uplifts in the northern margin of the Indian plate,NW Himalaya.Geological Survey \& Mines Beru, Srilanka,professional paper, 7,27-40.

Silva, P.G., Goy, J.L., Zazo, C., Bardaji, T., 2003. Fault generated mountain fronts in Southeast Spain: geomorphologic assessment of tectonic and earthquake activity. Geomorphology, 50, 203- 226.

Sreedevi, P.D., Subrahmanyam, K., Ahmed, S. 2005.lintegrated approach for delineating potential zones to explore for groundwater in the Pageru River basin, Kuddapah District, Andhra Pradesh, India. Hydrogeology Journal, 13. 534- 545.

Sreedevi P.D., Owais, S., Khan, H.H.2009. Morphometric analysis of a watershed of South India using SRTM data and GIS. J Geol Soc India, 73,543-552.

Strahler, A.N., 1952. Hypsometric (area-altitude) analysis of erosional topography. Geological Society of America Bulletin, 63, 1117-1142.

Strahler, A. N., 1957. Quantitative analysis of watershed geomorphology. Am Geophys Union Transactions 38, 913-920.

Strahler, A.N., 1964 Quantitative geomorphology of drainage basins and channel networks In. Handbook of Applied Hydrology, McGraw Hill Book Company, New York, Section 4II.

Taloora,A.K., Kumar, P.,Ray,., Jasrotia A.S.Kotlia,B.S., Alam, A., Kumar, S.G.,Kumar, R., Kumar, V., Roy,S. 2017. Active tectonic deformation along reactivated faults in Binta basin in Kumaun Himalaya of north India: Inferences from tectono-geomorphic evaluation.Zeitschrift für Geomorphologie, 61(2) ,DOI: 10.1127/zfg/2017/0417.

Thakur V. C., Rawat, B. S., 1992. Geologic Map of Western Himalaya, 1:1,000,000. Dehra Dun, India, Wadia Institute of Himalayan Geology.

Thakur, V. C., Pandey, A. K., Suresh, N., 2007. Late Quaternary-Holocene evolution of Dun structure and the Himalayan Frontal Fault zone of the Garhwal Sub-Himalaya, NW India, J. Asian Earth Sci., 29(2-3), 305-319, doi:10.1016/j.jseaes.2006.02.002.

Valdiya, K. S., 1980. Geology of Kumaun Lesser Himalaya. Wadia Institute of Himalayan Geology, Dehradun, 291.

Wadia, D.N., 1975. Geology of India. 4th edition. Tata McGraw-Hill Publishing Co., NewDelhi (Tenth reprint (1989).

Page $12 / 18$ 
Walker, C. B., Searle, M. P., Waters, D. J.,2001. An integrated tectonothermal model for the evolution of the High Himalaya in western Zanskar with constraints from thermobarometry and metamorphic modeling.Tectonics, 20(6), 810-833.

Wani, A. A., Bali, B. S.2017. Geomorphic analysis of relative tectonic activity in the Sindh Basin,Jammu and Kashmir Himalaya, northwest India. Journal of Himalayan Geology, 38(2),171-183.

Wani, A.A., Bali, B. S., Mohammad, S., 2019. “Drainage Characteristics of tectonically active area: An example from Mawar Basin, Jammu and Kashmir, India”. Journal of Geological Society of India, Vol 93(3),313-320.

Wani, A.A., Bali, B. S., Bhat,G. R., Hussain, N 2020. Impact of tectonics on drainage network evolution of Suru basin, Kargil N/w Himalaya, Jammu and Kashmir, India. Environmental Earth Sciences,79(1)

Wells,S., Bullard, T., Menges, C. M., Drake, P.G., Karas, P. A.,Kelson, K. I., Ritter, J. B., Wesling, J. R., 1988.Regional variations in tectonic geomorphology along segmented convergent plate boundary, Pacific coast of Coasta Rica.Geomorphology,1,239-265.

Whipple, K., Wobus, C., Crosby, B., Kirby, E., Sheenan, D., 2007. New tools for quantitative geomorphology: extracting and interpretation of stream profiles from digital topographic data. GSA annual meeting, Denver, Colorado.

Wobus, C., Heimsath, A. M., Whipple, K., Hodges, K. V., 2005. Active out-of-sequence thrust faulting in the central Nepalese Himalaya, Nature, 434(7036), 1008-101.

\section{Tables}

Table 1. Calculated eight geomorphic indices for 9 sub-basins and statistical summary of obtaine
\begin{tabular}{|l|r|r|r|r|r|l|l|l|}
\hline SNo. & Smf & Hi & Af & Rb & Ka & Eb & Si & Ff \\
\hline Sandran & 1.13 & 0.40 & 48 & 4.50 & 0.30 & 0.12 & 1.14 & 0.20 \\
\hline Veshaw & 1.09 & 0.49 & 70 & 3.60 & 0.38 & 0.15 & 1.40 & 0.34 \\
\hline Rambria & 1.14 & 0.51 & 61.2 & 3.56 & 0.30 & 0.11 & 1.20 & 0.19 \\
\hline Romushi & 1.15 & 0.38 & 63.3 & 3.08 & 0.24 & 0.11 & 1.32 & 0.28 \\
\hline Doodhganga & 1.10 & 0.23 & 21.62 & 3.78 & 0.31 & 0.13 & 1.30 & 0.41 \\
\hline Pohru & 1.30 & 0.23 & 47 & 4.25 & 0.57 & 0.17 & 1.36 & 0.70 \\
\hline Madhumati & 1.25 & 0.49 & 68.52 & 4.60 & 0.41 & 0.15 & 1.12 & 0.33 \\
\hline Erin & 1.20 & 0.46 & 32 & 5.10 & 0.46 & 0.17 & 1.12 & 0.34 \\
\hline Sindh & 1.29 & 0.40 & 62.7 & 4.18 & 0.24 & 0.09 & 1.28 & 0.23 \\
\hline
\end{tabular}

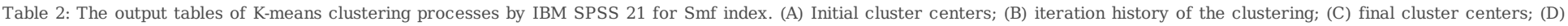
analysis of variance; (E) number of cases in each cluster.

(A)Initial Cluster Centers

\begin{tabular}{|c|c|c|c|}
\hline & \multicolumn{3}{|c|}{ Cluster } \\
\cline { 2 - 4 } & 1 & 2 & 3 \\
\hline Smf & 1.30 & 1.20 & 1.09 \\
\hline
\end{tabular}




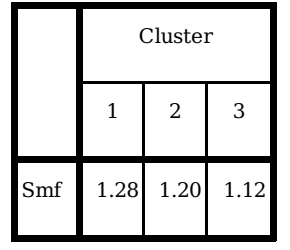

\begin{tabular}{|l|r|r|r|r|r|l|}
\hline \multirow{2}{*}{} & \multicolumn{2}{|c|}{ Cluster } & \multicolumn{2}{c|}{ Error } & \multirow{2}{*}{ F } & \multirow{2}{*}{ Sig. } \\
\cline { 2 - 6 } & Mean Square & df & Mean Square & df & F \\
\hline Smf & .024 & 2 & & .001 & 6 & 34.647 .001 \\
\hline
\end{tabular}

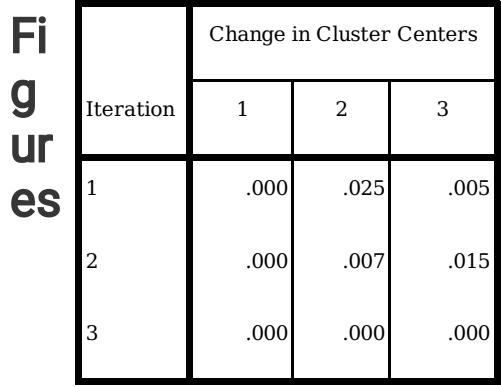

Table3: (A) The Pearson correlation (B) ANOVA output tables of clustering related to obtaining IRTA index

\begin{tabular}{|l|l|r|r|r|r|r|r|r|r|}
\hline 1. Pearson Correlation \\
\hline
\end{tabular}

*Correlation is significant at the 0.05 level $\quad * *$ Correlation is significant at the 0.01 level

\begin{tabular}{|c|c|c|c|c|c|c|}
\hline \multicolumn{7}{|c|}{ (B) ANOVA } \\
\hline & \multicolumn{2}{|l|}{ Cluster } & \multicolumn{2}{|l|}{ Error } & \multirow[t]{2}{*}{ F } & \multirow[t]{2}{*}{ Sig. } \\
\hline & Mean Square & $\mathrm{df}$ & Mean Square & df & & \\
\hline Ff & .024 & 2 & .024 & 6 & .994 & .424 \\
\hline Smf & .002 & 2 & .008 & 6 & .270 & .772 \\
\hline $\mathrm{Hi}$ & .018 & 2 & .009 & 6 & 1.912 & .228 \\
\hline Af & 1084.465 & 2 & 19.046 & 6 & 56.938 & .000 \\
\hline $\mathrm{Rb}$ & .407 & 2 & .384 & 6 & 1.060 & .403 \\
\hline $\mathrm{Ka}$ & .011 & 2 & .012 & 6 & .952 & .437 \\
\hline $\mathrm{Eb}$ & .001 & 2 & .001 & 6 & 1.063 & .403 \\
\hline Si & .002 & 2 & .015 & 6 & .144 & .869 \\
\hline
\end{tabular}

(E)Number of Cases in each Cluster

\begin{tabular}{|lr|r|}
\hline Cluster & 1 & 2 \\
& 2 & 2 \\
& 3 & 5.000 \\
& & 9.000 \\
Valid & .000 \\
\hline & & \\
\hline
\end{tabular}



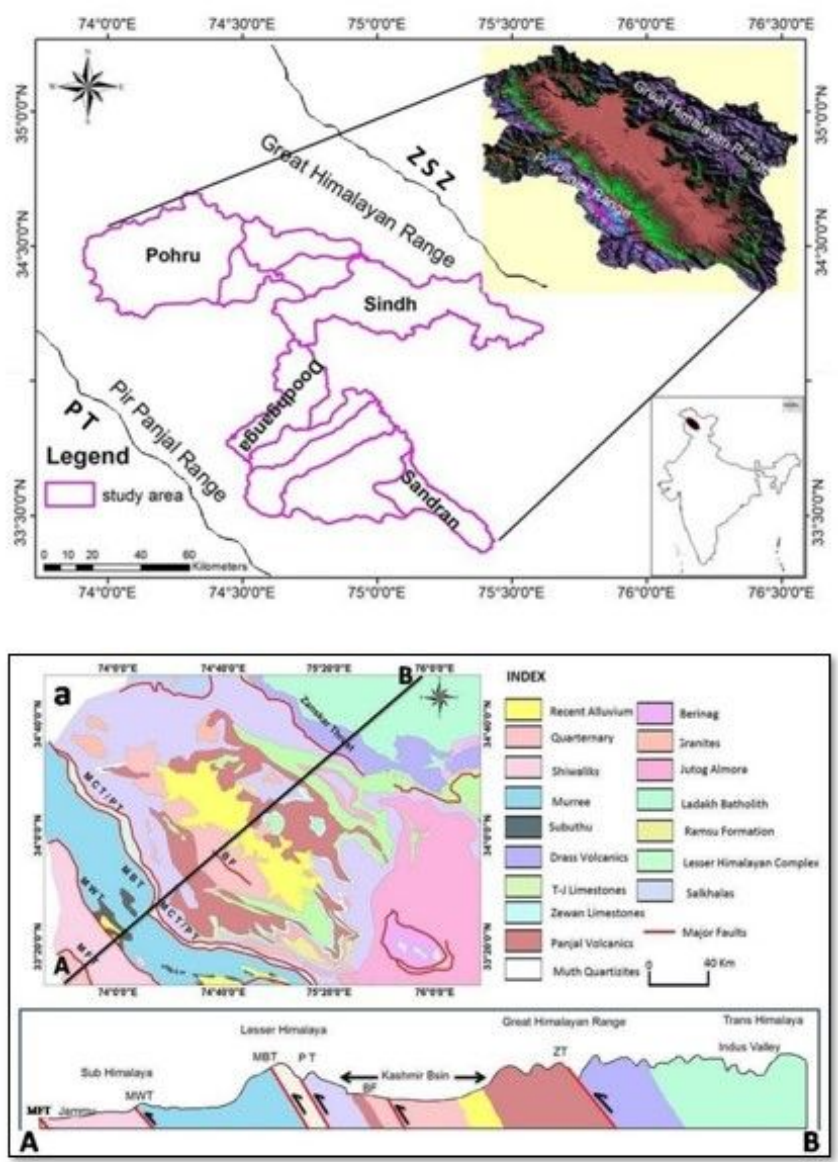

\section{Figure 1}

Study area map with major mountain Ranges (GHR and PPR) and tectonic elements: PT/Panjal Thrust and ZSZ Zanskar Shear Zone. Fig. 1b: Crossection of the faults (in and out of sequence) surrounding the Kashmir valley(ZT;Zanskar Thrust, BF; Balapora Fault, MCT/PT; Main Central Thrust/Panjal Thrust, MBT; Main Boundary Thrust, MWT; Medlicott Wadia Thrust, MFT; Main Frontal Thrust) (after Wani and Bali, 2018). Note: The designations employed and the presentation of the material on this map do not imply the expression of any opinion whatsoever on the part of Research Square concerning the legal status of any country, territory, city or area or of its authorities, or concerning the delimitation of its frontiers or boundaries. This map has been provided by the authors.

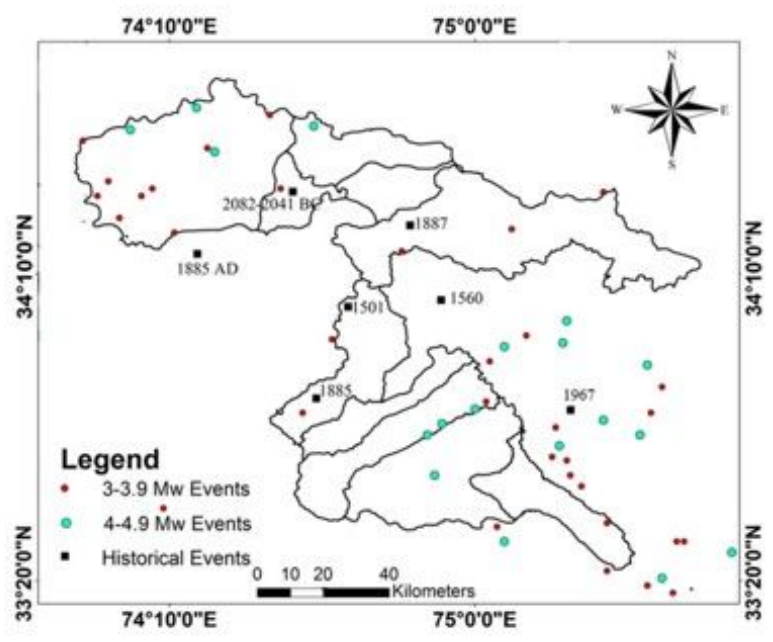

Figure 2 
Note: The designations employed and the presentation of the material on this map do not imply the expression of any opinion whatsoever on the part of Research Square concerning the legal status of any country, territory, city or area or of its authorities, or concerning the delimitation of its frontiers or boundaries. This map has been provided by the authors. Earthquake frequency and Historical earthquake event map after National Earthquake Information Catalogue [(NEIC); Ahmad and Muzamil, 2014; Ahmad et al., 2009].

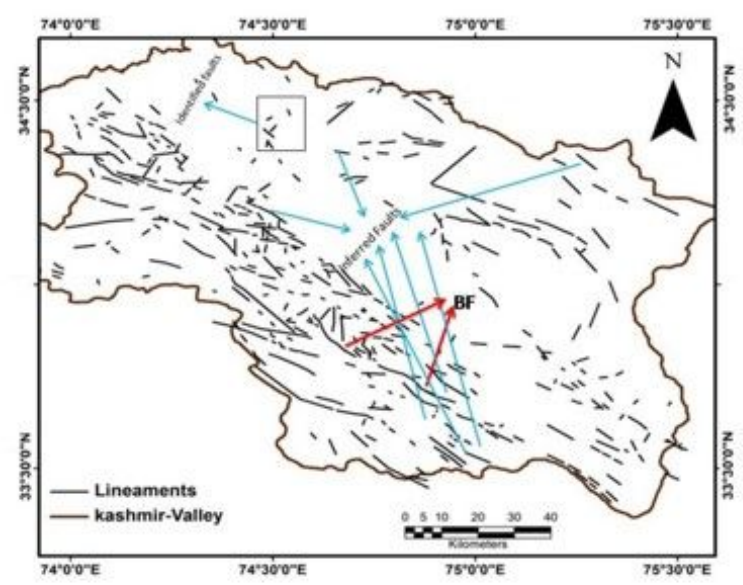

\section{Figure 3}

Lineament and fault map of the Kashmir valley after, Ahmed et al., 2013; Shah,2013; Ganju and Khar,1984;Datta,1983 (Red arrow indicate Balapora fault and blue arrows indicates Inferred faults). Note: The designations employed and the presentation of the material on this map do not imply the expression of any opinion whatsoever on the part of Research Square concerning the legal status of any country, territory, city or area or of its authorities, or concerning the delimitation of its frontiers or boundaries. This map has been provided by the authors.

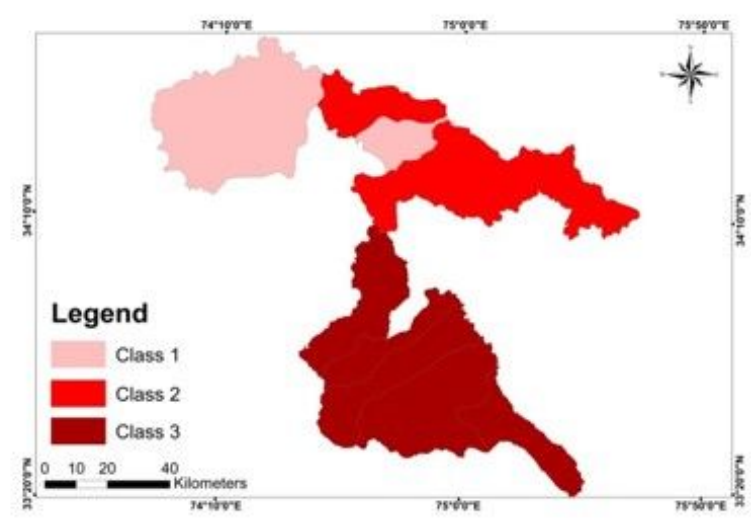

\section{Figure 4}

Classification map of the IRTA (index of relative tectonic activity) in the sub-basins along the ZSZ and PT; BF. Note: The designations employed and the presentation of the material on this map do not imply the expression of any opinion whatsoever on the part of Research Square concerning the legal status of any country, territory, city or area or of its authorities, or concerning the delimitation of its frontiers or boundaries. This map has been provided by the authors. 

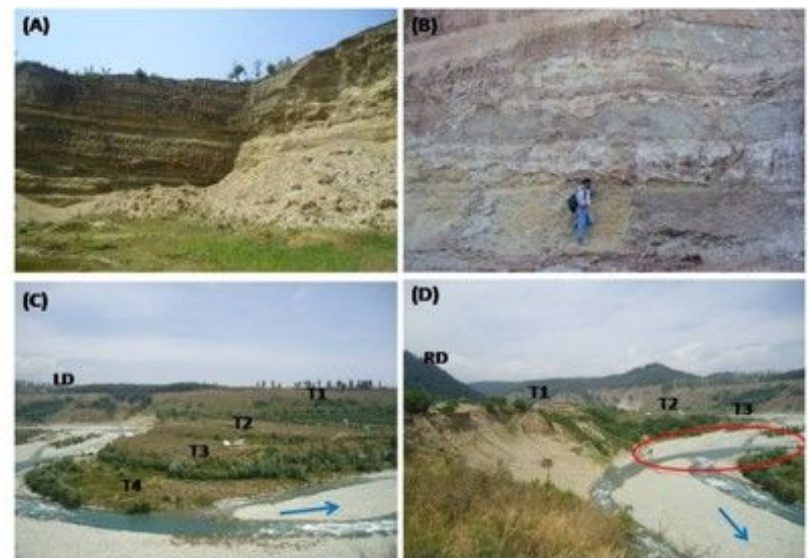

(D)

\section{Figure 5}

a) Dipping Karewa beds near Kuil, Chandpora (A\&B), Unpaired river terraces near Tangmarg (5C\&D) Where RD and LD are right bank and Left bank drainage divides respectively, Blue arrow indicates flow direction and red ellipse shows offset Veshaw river.
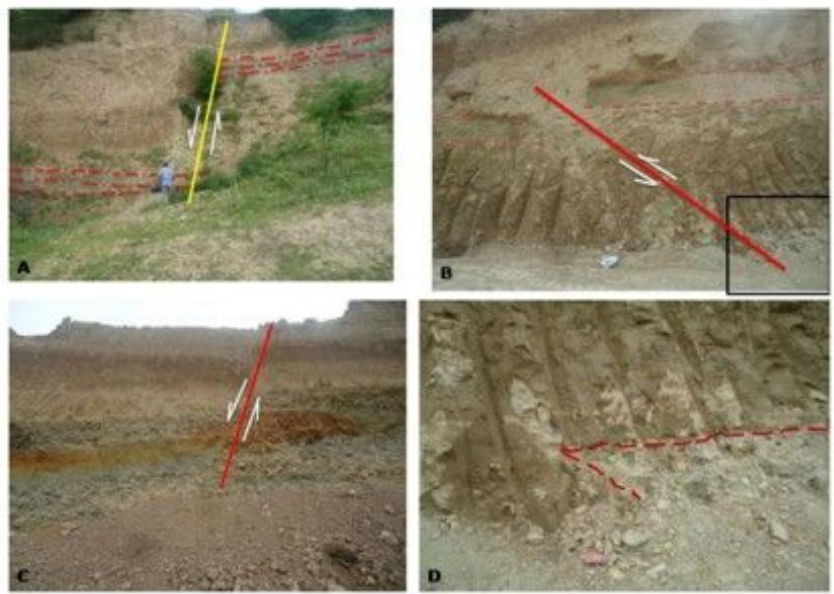

\section{Figure 6}

(A) Normal fault near Chandpora with 20 feet offset of boulder bed (B) Reverse fault with 2.5 feet offset (C) Normal fault near Gundipora with 1.5 feet offset (D) inset of reverse fault shown on (B).

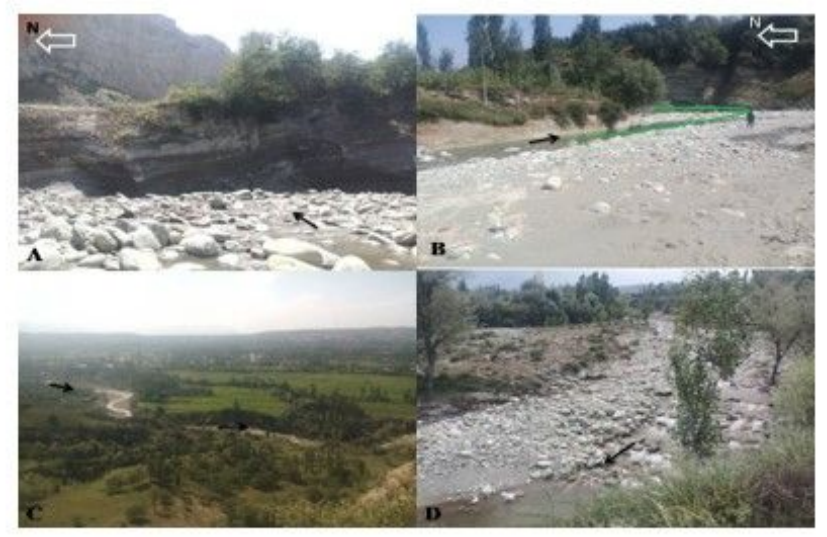

Figure 7 
A) Northeast dipping karewa beds near Arigam (B) Southwest dipping Karewa beds near Raithan and offset stream indicated by green line (C) Un paired river terraces and meandering of river (D) Braided bar deposit above fault plane (Black arrow indicate flow direction) 